Jurnal Keperawatan Silampari

Volume 5, Nomor 1, Desember 2021

e-ISSN: 2581-1975

p-ISSN: 2597-7482

DOI: https://doi.org/10.31539/jks.v5i1.1643

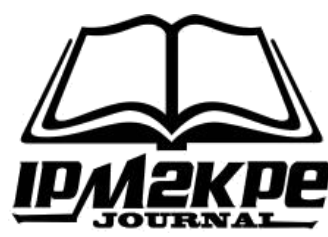

\title{
INDIRECT EFFECTS FAKTOR PERAN PADA IMPLEMENTASI PATIENT CENTER CARE TERHADAP PELAKSANAAN PATIENT SAFETY
}

\author{
Olivia Talahatu ${ }^{1}$, Muhammad $\mathrm{Hadi}^{2}$, Suhendar Sulaiman ${ }^{3}$ \\ Universitas Muhammadiyah Jakarta ${ }^{1,2,3}$ \\ olivetalahatu@gmail.com ${ }^{1}$
}

\begin{abstract}
ABSTRAK
Penelitian ini bertujuan untuk teridentifikasi faktor yang berperan pada implementasi PCC terhdap indikator mutu pelayanan rumah sakit (patient safety) berdasarkan dengan moderat motivasi kerja. Metode penelitian Pada penelitian ini menggunakan desain observasional analitikal dengan pendekatan cross sectional. Hasil penelitian ini diterima 3 hipotesis, diantaranya hubungan implementasi PCC terhadap patient safety, dan 2 inderect effect yakni peran implementasi PCC terhadap patient safety melalui motivasi kerja serta salah satu factor implementasi PCC (Pengukuran system dan tanggapan) terhadap patient safety. Simpulan, motivasi kerja terkait bentuk apresiasi atau reward merupakan indikator dengan nilai terbesar yang berpengaruh secara positif terhadap penerapan pasient safety jika di tunjang dengan dukungan faktor faktor yang berperan dalam pelaksanaan PCC di rumah sakit umum bhayangkara TK I R Said Sukanto Jakarta Timur sebagai salah satu rumah sakit militer
\end{abstract}

Kata Kunci : Implementasi PCC, Motivasi Kerja, Patient safety

\begin{abstract}
This study aims to identify factors that play a role in PCC implementation on indicators of hospital service quality (patient safety) based on moderate work motivation. Research method This research uses an analytical observational design with a cross-sectional approach. The results of this study accepted three hypotheses, including the relationship between PCC implementation and patient safety and two indirect effects, namely the role of PCC implementation on patient safety through work motivation and one of the factors of PCC implementation (Measurement of systems and responses) to patient safety. In conclusion, work motivation related to the form of appreciation or reward is the indicator with the most significant value that has a positive effect on the implementation of patient safety if it is supported by the support of factors that play a role in the performance of PCC in the Bhayangkara General Hospital TK IR Said Sukanto, East Jakarta as one of the hospitals. military
\end{abstract}

Keywords: PCC Implementation, Work Motivation, Patient safety

\section{PENDAHULUAN}

Rumah sakit adalah suatu institusi yang memberikan pelayanan kesehatan secara paripurna bagi seseorang, keluarga atau kelompok dengan memberikan pelayanan rawat inap, rawat jalan, dan gawat darurat. Di Indonesia, rumah sakit sebagai salah satu sistem 
pelayanan kesehatan yang memberikan pelayanan kepada masyarakat berupa pelayanan kesehatan, meliputi pelayanan medik, pelayanan penunjang medik, rehabilitasi medik dan pelayanan keperawatan (Ernawati \& Lusiani, 2019).

Patient center care atau yang disingkat PCC merupakan suatu model pelaksanaan pelayanan kesehatan yang berpusat pada pasien dimana pasien menjadi aktif dalam perawatan status kesehatannya. Penelitian ini menguraikan faktor yang berperan dalam implementasi PCC terhadap pelaksanan patient safety, dimana Patient safety juga merupakan bagian dari implementasi PCC, factor yang berperan dalam implementasi PCC dilakukan moderasi dengan motivasi kerja dan juga dilakukan salah indirect effect pada salah satu factor yang berperan dalam pelaksanaan implementasi PCC yakni PST atau pengukuran system dan tanggapan.

World Health Organization (WHO) menyatakan keselamatan pasien merupakan masalah kesehatan masyarakat global yang serius. Kesalahan medis dapat disebabkan oleh faktor sistem dan faktor manusia. Insiden keselamatan pasien yang merugikan adalah terkait dengan prosedur bedah (27\%), kesalahan pengobatan (18,3\%), dan kesehatan infeksi terkait perawatan (12,2\%) (Yusuf, 2017). WHO mendefenisikan patient safety adalah pencegahan kesalahan dan efek samping untuk pasien yang berkaitan dengan pelayanan Kesehatan. WHO pada tahun 2004 mengumpulkan angka-angka penelitian rumah sakit di berbagai negara: Amerika, Inggris, Denmark, dan Australia, ditemukan KTD dengan rentang 3,2 16,6\%. Data tersebut menjadi pemicu berbagai negara segera melakukan penelitian dan mengembangkan sistem keselamatan pasien (Fitri et al., 2020).

Dari penelitian sebelumnya yang dilakukan oleh Rahmi (2021) menunjukkan bahwa tidak ada hubungan pengetahuan dengan penerapan patient safety $(p=0.144)$. Terdapat hubungan yang signifikan antara variabel sikap dan motivasi dengan penerapan patient savety yakni nilai $p$ masing-masing sebesar 0,000. Sikap dan motivasi memengaruhi penerapan patient savety oleh perawat. Jika sikap dan motivasi perawat baik, maka penerapan patient safety dapat dilaksanakan dengan baik.

Berdasarkan hasil studi pendahuluan yang dilakukan di RSU Bhayangkara TK I. R Said Sukanto Jakarta Timur dari hasil wawancara yang dilakukan bersama kepala bagian keperawatan diungkapkan bahwa rumah sakit sudah menerapkan standar akreditasi SNARS Edisi 1 Januari 2018 dengan demikian terus berupaya untuk menuju system model penerapan PCC, selanjutnya kaitannya pelaksanaan patient safety oleh perawat pelaksana sendiri masih menjadi catatan penting, beliau mengatakan bahwa untuk kepatuhan akan sasaran patient safety juga masih sangat rendah walau upaya supervisi sudah dilakukan secara rutin akan tetapi secara keseluruhan pada setiap standar goals masih perlu di tingkatkan. Hal tersebut sejalan dengan hasil akreditasi SNARS Edisi 1 januari 2018 yang dilakukan oleh RSU Bhayangkara TK.I R Said Sukanto Jakarta Timur yang memberikan catatan penting pada hasil evaluasi pencapaian standar patient safety.

Dengan fenomena yang ada pada rumah sakit bhayangkara TK I R. Said Sukanto Jakarta Timur peneliti melakukan penelitian yakni mengevaluasi sejauh mana peranan implementasi PCC terhadap pencapaian indikator mutu pelayanan rumah sakit yaitu patient safety dengan dimoderatkan oleh motivasi kerja perawat pelaksana (Ners). Tujuan dampak implementasi PCC turut menjadi factor yang penting dalam mengontrol bahkan mendukung dan mengoptimalkan pelaksanaan patient safety di rumah sakit. 


\section{METODE PENELITIAN}

Metode penelitian pada penelitian ini adalah observasional desain analitikal dengan pendekatan cross sectional. Teknik pengumpulan data secara keseluruhan menggunakan kuisioner dalam bentuk online melalui google form dengan skala Likert. Untuk uji validitas kuesioner dilakukan hanya pada variabel implementasi PCC. Alat ukur yang di ambil untuk variable implementasi PCC melalui 7 faktor yang berperan dalam implementasi PCC dan hasil reability Cronbach's Alpha 0,87. Penelitian ini telah dilakukan dari bulan awal Juli sampai akhir Juli 2020 di Rumah Sakit Umum Bhayangkara TK I R. S Sukanto Jakarta

Timur. Populasi dalam penelitian ini adalah Ners : 139 orang dan tersebar pada beberapa unit layanan rawat inap dan Sampel mengancu pada Rumus Solvin dengan kelonggaran $20 \%$ sehingga sampel 30 responden. Teknik pengambilan sampel adalah non probability yaitu (kuota) dikarena keterbatasan peneliti pada kondisi pandemic covid 19. Pada analisis data selain analisa univariat juga menggunakan analisa bivariate (uji korelasi) dan untuk analisa multivariat menggunakan sofeware PLS Profesional versi 3.2.9 dengan menggunakan uji jalur. Pengujian hipotesis yakni hubungan antar laten dan 2 inderect effect. Berikut kerangka analisisnya.

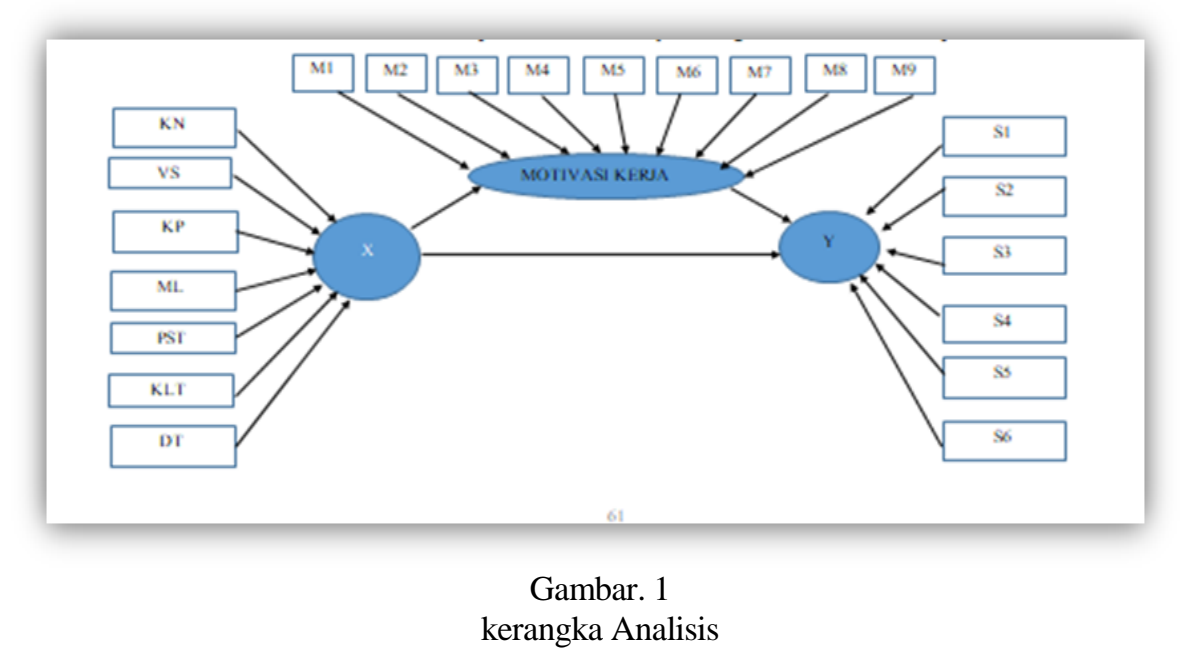

\section{HASIL PENELITIAN}

\section{Evaluasi Outer Model}

Pengujian yang dilakukan pada analisa outer model yaitu convergent validity, composite reability, Average Variance Extracted (AVE) dan Cronbach's Alpha.

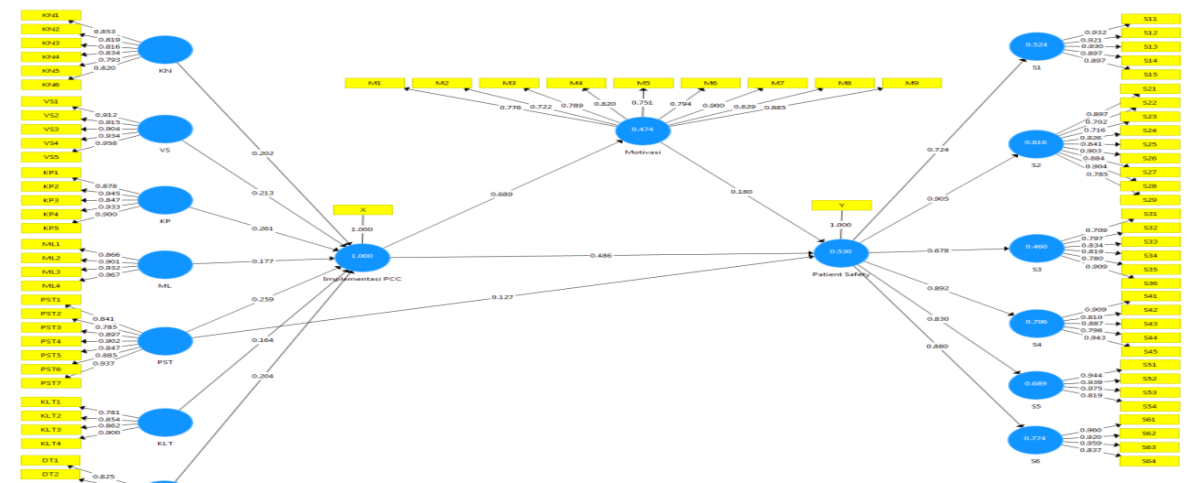

Gambar. 2

Model Konstruk 


\section{Structural Model (Inner Model)}

Setelah melakukan evaluasi model dan diperoleh bahwa setiap konstruk telah memenuhi syarat covergent valdity, discriminant validity, dan composite reliability, maka yang berikutnya adalah evaluasi model structural yang meliputi pengujian path.

Model structural di evaluasi dengan menggunakan R-square untuk konstruk dependen, Stone-Geiser Q-square test untuk predictive relevan. Nilai $\mathrm{R}^{2}$ dapat digunakan untuk menilai pengaruh variabel laten independen tertentu, variabel laten dependen apakah mempunyai pengaruh substantive. Semakin tinggi nilai $\mathrm{R}^{2}$ maka semakin besar kemampuan variabel laten indipenden dapat menjelaskan variabel laten dependen. Hasil $\mathrm{R}^{2}$ sebesar 0.67, 0.33, dan 0.19 mengindikasi bahwa model "baik", "moderat", dan "lemah".

Tabel. 1

R-squared coefficients

\begin{tabular}{lc}
\hline \multicolumn{1}{c}{ Variabel } & $\mathrm{R}-$ Square \\
\hline Motivasi & 0.474 \\
Implementasi PCC & 1.000 \\
Patient safety & 0.530 \\
\hline
\end{tabular}

Berdasarkan tabel 1 diperoleh nilai R-Square untuk variabel motivasi sebesar 0.474 hal ini hal ini berarti $47.4 \%$ variasi atau perubahan Motivasi dipengaruhi oleh Implementasi PCC. Berdasarkan hal tersebut maka hasil perhitungan $\mathrm{R}^{2}$ menunjukkan bahwa $\mathrm{R}^{2}$ termasuk Moderat. Berdasarkan tabel 5 diperoleh nilai R-Square untuk variabel Implementasi PCC sebesar 1.000, hal ini hal ini berarti $100 \%$ variasi atau perubahan Implementasi PCC dipengaruhi oleh faktor KN (kepemimpinan), VS (visi strategis), KP (keterlibatan pasien dan keluarga), ML (memperhatikan lingkungan sebagai perawatan), PST (pengukuran sistematis dan pengukuran), KLT (kualitas lingkungan) dan DT(dukungan teknologi), sedangkan sisanya sebanyak 0\% dijelaskan oleh sebab lain. Berdasarkan hal tersebut maka hasil perhitungan $\mathrm{R}^{2}$ menunjukkan bahwa $\mathrm{R}^{2}$ termasuk Baik. Berdasarkan tabel 5 diperoleh nilai R-Square untuk variabel Patient safety sebesar 0.530, hal ini hal ini berarti 53\% variasi atau perubahan Patient safety dipengaruhi oleh Motivasi dan faktor - faktor Implementasi PCC, sedangkan sisanya sebanyak $47 \%$ dijelaskan oleh sebab lain. Berdasarkan hal tersebut maka hasil perhitungan $\mathrm{R}^{2}$ menunjukkan bahwa $\mathrm{R}^{2}$ termasuk Moderat.

Disamping melihat nilai R-square, model juga dievaluasi dengan melihat Q-square prediktif relevansi untuk model konstruktif. Q-square mengukur seberapa baik nilai observasi dihasilkan oleh model dan juga estimasi parameternya. Besaran $\mathrm{Q}^{2}$ memiliki nilai rentang $0<\mathrm{Q}^{2}<1$, dimana semakin mendekati 1 berarti model semakin baik. Besaran $\mathrm{Q}^{2}$ ini setara dengan koefisien determinasi total pada analisis jalur path (path analysis). Nilai $\mathrm{Q}^{2}>$ 0 menunjukan model memilki prediktif relevansi, sebaliknya jika nilai $\mathrm{Q}^{2} \leq 0$ menunjukan model kurang memiliki prediktif relevansi.

Perhitungan $\mathrm{Q}^{2}$ total variabel Job Stress dilakukan dengan rumus:

Q-Square

$=1-[(1-R 21) \times(1-R 22) \times(1-R 23)]$

$=1-[1-0.474) \times(1-1.000) \times(1-0.470)]$

$=1-(0.526 \times 0.000 \times 0.470)$

$=1-0.0000078$

$=0.999922$ 
Nilai tersebut menunjukan bahwa informasi yang terkandung dalam data $99.9922 \%$ dapat dijelaskan oleh model, sedangkan $0.0000078 \%$ dijelaskan oleh variabel lain (yang belum terdapat didalam model), serta unsur error.

\section{Hasil Bootstrapping}

Dalam PLS, pengujian setiap hubungan dilakukan dengan menggunakan simulasi dengan metode bootstrapping terhadap sampel. Pengujian ini bertujuan untuk meminimalkan masalah ketidak normalan dalam penelitian. Hasil pengujian dengan metode bootstrapping dari PLS sebagai berikut:

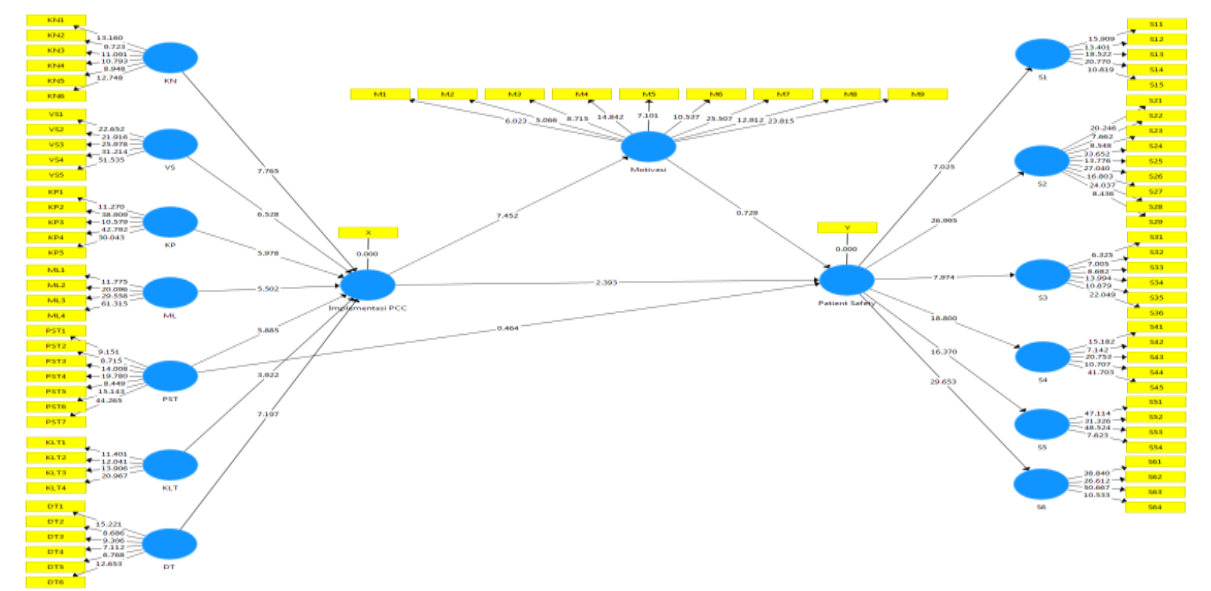

Gambar. 3

Diagram Path

Tabel. 2

Path Coefficients

\begin{tabular}{lccccc}
\hline & $\begin{array}{c}\text { Original } \\
\text { Sample } \\
(\mathrm{O})\end{array}$ & $\begin{array}{c}\text { Sample } \\
\text { Mean } \\
(\mathrm{M})\end{array}$ & $\begin{array}{c}\text { Standard } \\
\text { Deviation } \\
(\text { STDEV })\end{array}$ & $\begin{array}{c}\text { T Statistics } \\
(|\mathrm{O} / \mathrm{STDEV}|)\end{array}$ & $\begin{array}{c}\mathrm{P} \\
\text { Values }\end{array}$ \\
\hline KN -> Implementasi PCC & 0.202 & 0.198 & 0.026 & 7.765 & 0.000 \\
VS -> Implementasi PCC & 0.213 & 0.210 & 0.033 & 6.528 & 0.000 \\
KP -> Implementasi PCC & 0.261 & 0.259 & 0.044 & 5.978 & 0.000 \\
ML -> Implementasi PCC & 0.177 & 0.172 & 0.032 & 5.502 & 0.000 \\
PST -> Implementasi PCC & 0.259 & 0.249 & 0.044 & 5.885 & 0.000 \\
KLT -> Implementasi PCC & 0.164 & 0.171 & 0.042 & 3.922 & 0.000 \\
DT -> Implementasi PCC & 0.204 & 0.206 & 0.028 & 7.197 & 0.000 \\
Implementasi PCC -> Patient & 0.486 & 0.469 & 0.203 & 2.393 & 0.017 \\
safety & & & & & \\
PST -> Patient safety & 0.127 & 0.116 & 0.273 & 0.464 & 0.643 \\
\hline
\end{tabular}

Berdasarkan tabel 2 menunjukkan hasil perhitungan PLS yang menyatakan pengaruh langsung antar variabel. Dikatakan ada pengaruh langsung jika nilai T Statistics $>1.96$ dan dikatakan tidak ada pengaruh jika $\mathrm{T}$ statistics $<1.96$. Berdasarkan tabel di atas maka dapat dinyatakan bahwa setiap factor dari implementasi PCC berpengaruh signifikan terhadap implementasi dengan nilai $\mathrm{T}$ Statistics > 1.96 dan tanpa terkecuali juga pada faktor pengukuran sistematis dan tanggapan (PST) berpengaruh signifikan terhadap variabel Implementasi PCC dengan nilai T Statistics > 1.96. dan selanjutnya variable Implementasi PCC berpengaruh signifikan terhadap variabel patient safety dengan nilai $\mathrm{T}$ Statistics > 1.96. 
Tabel. 3

Specific Indirect Effects

\begin{tabular}{lccccc}
\hline & $\begin{array}{c}\text { Original } \\
\text { Sample } \\
(\mathrm{O})\end{array}$ & $\begin{array}{c}\text { Sample } \\
\text { Mean } \\
(\mathrm{M})\end{array}$ & $\begin{array}{c}\text { Standard } \\
\text { Deviation } \\
(\text { STDEV })\end{array}$ & $\begin{array}{c}\text { T Statistics } \\
(\mid \mathrm{O} / \mathrm{STDEV})\end{array}$ & $\begin{array}{c}\mathrm{P} \\
\text { Values }\end{array}$ \\
\hline $\begin{array}{l}\text { PST -> Implementasi PCC -> } \\
\text { Patient safety }\end{array}$ & 0.126 & 0.116 & 0.052 & 2.399 & 0.017 \\
$\begin{array}{l}\text { Implementasi PCC -> } \\
\text { Motivasi Kerja -> Patient } \\
\text { safety }\end{array}$ & 0.132 & 0.125 & 0.061 & 2.430 & 0.021 \\
\hline
\end{tabular}

Berdasarkan tabel 7 Specific Indirect Effects di atas, diketahui bahwa dari 1 pengaruh mediasi dinyatakan berpengaruh signifikan. Suatu hipotesis dinyatakan dapat diterima atau berpengaruh signifikan apabila T-Statistic sesuai dengan standar T-Table yaitu memiliki nilai $>1.96$ dan memiliki nilai $\mathrm{P}$ Values yaitu $<0,05$ pada kedua variable, yaitu implementasi PCC dan salah satu indicator dari implementasi PCC yaitu Pengukuran sistematis dan tanggapan (PST).

\section{PEMBAHASAN}

\section{Hubungan Implementasi PCC terhadap Patient Safety}

Berdasarkan hasil penenlitian terdapat hubungan secara signifikan antara implementasi PCC terhadap Patient safety hal ini terbukti dengan nilai T-Statestic 2393 yang artinya adalah semakin baik implementasi PCC maka semakin baik pula pelaksanaan patient safety. Dengan demikian bahwa secara langsung dalam 7 faktor yang berperan dalam implementasi PCC mampu memberikan pengaruh secara positif terhadap penerapan pastient safety. Terkait keterlibatan pasien dan keluarga yang mungkin sudah diterapkan secara maksimal di rumah sakit bhayangkara TK I R Said Sukanto yang sudah terlaksana akan tetapi masih perlu ditingkatkan kembali dan diberi perhatian lebih.

Selanjutnya keterlibatan pasien dan keluarga sebagai yang menjadi salah satu faktor dari implementasi PCC dengan basic pointnya adalah komunikasi. Komunikasi merupakan hal yang penting dalam mewujudkan good goverance dan clinical dalam sebuah pelayanan jasa yang bersifat langsung yaitu rumah sakit. Sejalan dengan patient sfaety, dari hasil penelitian dengan survei yang dilakukan oleh Hal tersebut sejalan dengan penelitian yag dilakukan oleh Ernawati \& Lusiani (2019) mengungkapkan bahwa pelaksanaan patient center care dari prespektif pasien adalah kurang informasi kesehatan yang diterima dan dukungan keluarga yang dibutuhkan.

Berdasarkan penelitian yang dilakukan oleh Lai et al., (2020) dikemukakan bahwa implementasi PCC membutuhkan dukungan dari setiap stackholer terlebih dalam menerapkan transformasi budaya patient safety, menurut hasil penelitiannya bahwa pendekatan yang paling tepat dalam meningkatkan dan pengoptimalan pelaksanaan patient safety di lapangan lebih efektif melalui pasien di bandingkan dengan suatu sistem teoritis menurut para ahli.

Dengan demikian diharapakan pelaksanaan faktor yang berperan dalam implementasi PCC dapat di jawab secara utuh oleh rumah sakit bahayngkara TK I R Said Sukanto maka penerapan pasient safety akan semakin baik sehingga angka sasaran dalam pencapaian pasient safety sesuai dengan yang di. Di butuhkan kerja sama dari setiap stackholder dalam setiap pencapaian faktor yang berperan tersebut. 


\section{Pengaruh Tidak Langsung Implementasi PCC terhadap Patient safety MELALUI Motivasi Kerja}

Dari hasil penelitian pada table 7 dengan nilai T-statistics 2.378 yang berarti $>1.96$ maka $\mathrm{H}_{2}$ diterima yang berarti bahwa motivasi kerja mempunyai pengaruh yang positif dan signifikan terhadap pasient safety. Bersadarkan hasil evaluasi outer loading pada variable intervening yaitu motivasi kerja di dapatkan bahwa indokator (M9) memberi pengaruh yang sangat besar pada variable motivasi kerja yaitu pemberian penghargaan dalam bentuk pujian di samping indikator lainnya.

Motivasi merupakan suatu dorongan yang dipengaruhi secara intrinsik dan ekstrinsik dalam diri seseorang untuk bertindak melakukan sesuatu sehingga mendaptkan kepuasan. Begitupun dalam pelaksanaan patient safety jika motivasi kerja perawat secara interistik tidak didorong oleh motivasi ekstrinsik yaitu berupa kebijakan dari rumah sakit maka penerapan dan pelaksanaannya tidak ada berlangsung secara optimal. Hal tersebut didukung juga dengan penelitian yang dilakukan oleh Morika et al., (2018) bahwa ada hubungan antara motivasi dengan kinerja perawat pelaksana dalam menerapkan patient safety.

Pelaksanaan patient safety melalui reward atau penghargaan kepada perawat telah terbukti banyak memberikan dampak yang baik, hal tersebut didukung oleh penelitian yang dilakukan oleh Vonna \& Yusuf (2016) mengungkapkan bahwa ada hubungan antara imbalan tidak langsung dan penerapan patient safety dengan demikian diharapkan rumah sakit umum Bhayangkara TK I R Said Sukanto dapat memperhatikan indikator penghargaan atau reward tak langsung ini sebagai salah satu upaya meningkatkan motivasi kerja perawat pelaksana dalam melakukan proses asuhan keperawatan karena Dalam penerapan patient safety secara optimal membutuhkan kinerja yang baik dari perawat. Selain itu dalam penerapan manajemen safety dipengaruhi oleh faktor psikologis yaitu reward secara langsung pujian atau apresiasi kepada pelaksana penerapan patient safety, karena berdasarkan beberapa penelitian yang dilakukan mengungkapkan bahwa tidak selamanya imbalan tidak langsung menjadi prioritas dukungan penerapan patient safety.

\section{Pengaruh Tidak Langsung Pengukuran Sistematis dan Tanggapan (PST) terhadap Patient Safety Melalui Motivasi}

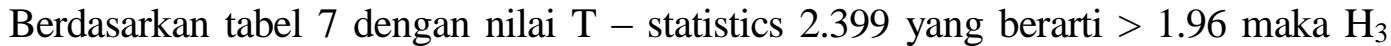
diterima yang berati bahwa pengukuran sistematis dan tanggapan (PST) mempunyai pengaruh yang positif dan signifikan terhadap Patient safety melalaui implementasi PCC. Hal ini berarti Jika implementasi PCC meningkat, maka hal tersebut menyebabkan peningkatan hubungan antara pengukuran sistematis dan tanggapan (PST) dengan patient safety harus melalui implementasi PCC dan motivasi.

Dari penelitian sebelumnya yang dilakukan oleh Rahmi et al., (2021) menunjukkan bahwa tidak ada hubungan pengetahuan dengan penerapan patient safety $(p=0.144)$. Terdapat hubungan yang signifikan antara variabel sikap dan motivasi dengan penerapan patient savety yakni nilai $p$ masing-masing sebesar 0,000 . Perawat dengan motivasi cukup dan tidak menerapkan patient safety disebabkan oleh kondisi fisik perawat sehingga tidak menerapkan patient safety, sedangkan perawat dengan motivasi kurang tidak memanfaatkan dikarenakan perawat mengharapkan adanya penghargaan bagi perawat yang disiplin dalam menerapkan patient safety sehingga semua perawat mempunyai motivasi dalam menerapkan patient safety pada pasien yang di layani.

Pengukuran Sistematis dan tanggapan merupakan suatu faktor yang mempengaruhi implementasi PCC dimana konsumen (pasien dan keluarga) dengan leluasan diberikan askes dan prosedur jelas dalam melakukan evaluasi terhadap kualitas layanan yang 
diberikan oleh rumah sakit. Sehingga diharapkan bahwa nilai nilai dan kebutuhan konsumen dapat lebih mudah dipahami oleh rumah sakit dan dengan demikian memudahkan dalam implementasi PCC dan juga rumah sakit dalam melakukan monitoring terhadap pelaksanaan patient safety juga lebih terkontrol dengan baik bahkan dalam hal pencegahan sekalipun.

\section{SIMPULAN}

Factor yang berperan pada implementasi PCC memberikan dampak yang baik bagi penerapan patient safety secara langsung dan membutuhkan kesatuan factor jika salah satu factor yang berperan baik belum terlalu kuat dalam memberikan dampak dalam penerapan patient safety.

Motivasi kerja terkait bentuk apresiasi atau reward merupakan indikator dengan nilai terbesar yang berpengaruh secara positif terhadap penerapan pasient safety jika di tunjang dukungan faktor faktor yang berperan dalam pelaksanaan PCC di rumah sakit umum bhayangkara TK I R Said Sukanto Jakarta Timur sebagai salah satu rumah sakit militer.

\section{SARAN}

Penelitian selanjutnya diharapkan untuk menelaah lebih dalam lagi secara kualitatif terkait dengan faktor - faktor yang berperan dalam implementasi PCC dengan melibatkan kelompok PPA atau secara khusus dan focus pada salah satu factor sesuai dengan permasalahan dan kebutuhan.

\section{DAFTAR PUSTAKA}

Ernawati, E., \& Lusiani, M. (2019). Studi Fenomenologi: Pelaksanaan Patient Center Care Perspektif Pasien dan Perawat di RS dr. Dradjat Prawiranegara Serang. Faletehan Health Journal, 6(3), 83-90. https://doi.org/10.33746/fhj.v6i3.17

Fitri, E. S., Kusnanto, K., \& Maryanti, H. (2020). Pengetahuan dan Sikap Perawat Berhubungan dengan Pelaksanaan Patient Safety. Jurnal Keperawatan Terpadu (Integrated Nursing Journal), 2(1), 22. https://doi.org/10.32807/jkt.v2i1.42

Lai, A. Y., Yuan, C. T., Marsteller, J. A., Hannum, S. M., Lasser, E. C., Heughan, J. A. A., Oberlander, T., Berger, Z. D., Gurses, A. P., Kharrazi, H., Pitts, S. I., Scholle, S. H., \& Dy, S. M. (2020). Patient Safety in Primary Care: Conceptual Meanings to the Health Care Team and Patients. Journal of the American Board of Family Medicine, 33(5), 754-764. https://doi.org/10.3122/JABFM.2020.05.200042

Morika, H. D., Suharizal, S., \& Yasmi, Y. (2018). Motivasi dengan Kinerja Perawat Pelaksana dalam Menerapkan Keselamatan Pasien. Jurnal Kesehatan Medika Saintika, 9(2), 1. https://doi.org/10.30633/jkms.v9i2.167

Rahmi, N. A., Ahri, R. A., \& Andayani, E. (2020). Hubungan Pengetahuan, Sikap dan Motivasi Perawat dengan Penerapan Patient Safety di RSUD Labuang Baji. Window of Public Health Journal, 2(1), 863-871. http://jurnal.fkm.umi.ac.id/index.php/woph/article/view/woph2106

Vonna, A., \& Yusuf, M. (2016). Pemberian Imbalan terhadap Penerapan Patient Safety Di RSUD dr. Zainoel Abidin. Kesehatan Masyarakat, 1-9. https://etd.unsyiah.ac.id/index.php?p=show_detail\&id=25246

Yusuf, M. (2017). Penerapan Patient Safety di Ruang Rawat Inap Rumah Sakit Umum Daerah Dr. Zainoel Abidin. Jurnal Ilmu Keperawatan, 5(1), 84-89. http://www.jurnal.unsyiah.ac.id/JIK/article/view/8766 